\title{
Educational Activities Concerning Folk/Popular Culture in Greek Primary School Websites
}

\section{Rea Kakampoura, Assistant Professor of Folkloristics}

Department of Primary Education, National and Kapodistrian University of Athens

George Katsadoros, Assistant Professor of Folkloristics

Department of Primary Education, University of the Aegean

\section{Aphrodite Nounanaki, PhD Candidate}

Department of Primary Education, National and Kapodistrian University of Athens

\section{Dimitris Kolokythas, PhD Candidate}

Department of Preschool Education Sciences and Educational Design, University of the Aegean

Abstract

Folk/Popular culture comprises a many-sided and complex term, existing in both its traditional (Folk) and contemporary dimension (Popular). Many of its aspects can be traced in Primary Education school books, but in many cultural school displays as well. Student participation in cultural oriented activities encourages enculturation, the awareness of belonging in one or many cultural groups, and, successively, an understanding of one's cultural identity.

This article presents the results of research conducted all over Greece concerning educational programs and activities about folk/popular culture as shown in the websites of Greek public and private Primary Schools and Kindergartens, utilizing online data collection.

Keywords: Folk/Popular Culture, Primary School, School Websites, Educational Activities

\section{Introduction}

Our paper focuses on the results of a research ${ }^{13}$ conducted in Greek primary school websites, blogs and social media sites; it concerns

13 This research was founded by the Special Account for Research Grants, National and Kapodistrian University of Athens. 
educational programs and activities related to folk/popular culture. Our aim is to seek, to record, to categorize and to statistically analyze such activities posted by teachers between 2000 to 2013 in Greek primary school official or unofficial websites of kindergartens and primary schools, both public and private.

The main questions of our research are:

$>\quad$ Which aspects of folk/popular culture do teachers choose from in order to organize various cultural activities both inside and outside of schools?

$>\quad$ What kind of activities are chosen (Ministry of Education programs, school projects, festivities, educational excursions, etc.)?

$>\quad$ Which are the most 'popular' teaching methods?

$>\quad$ How are these activities presented on the internet (texts, photographs, videos)?

\section{Theoretical Discussion}

The term folk/popular culture is multi-dimensioned and historically defined. It includes: 1) traditional, pre-industrial folk culture ${ }^{14}$ of mainly rural areas. In Greece it was active -mostly in rural areas- until the Second World War and its main characteristics were an agricultural or trading, mainly pre-capitalist, economy; small communities, mostly oral transmission and acceptance of notions, habits and practices from generation to generation (oral tradition and customs); dominance of medieval, pre-logical world views; collectiveness; combination and collaboration of practicality and aesthetics in folk art and 2) modern popular culture ${ }^{15}$, as it is variously and constantly shaped under the influence of an hegemonic western culture and cultural industry, sometimes in accordance sometimes opposed to the homogenizing cultural model of globalization. As aspect of popular culture one could regard the consumption of homogenized cultural products on a global level (i.e. MacDonald's), but also the transformation of folk culture aspects and their modern notions and uses (i.e. traditional food/ethnic cuisines, music or dances, folk tales in the movie industry, tourist and educational exploitation of traditional sites).

According to Hall (1987), postmodern subjects' identity is not permanent but ever changing. As cultural representations systems are multiplied, people tend to shape hybrid cultural identities from various cultural traditions (Hall-Held-McGrew, 2003); that applies especially to

${ }^{14}$ Folk Culture consists a main field of international folkloristic and ethnological studies. See Kyriakidou-Nestoros, 1989: 41-55.

${ }^{15}$ Popular Culture is a field of cultural studies. For an analytical critical view of cultural theory see Storey, 2012. For a theoretical discussion of the terms folk and popular see Avdikos, 2009. 
people such as immigrants or refugees. School education, as an institution, aims not only to socialize children, that is to instruct them in the ways a person becomes a full member of a social group, but also to enculturate, to make them realize that every person belongs to one or many cultural groups (Hollins, 1996). Children become members of the cultural groups they are raised into, gradually acquiring corresponding ways of thinking, of feeling, of behaving. Socio-historical analysis of shifting folk cultures of national, ethnic or religious groups, is crucial for multicultural education that helps children to realize elements that define their own cultural identity, but others' identity as well. Folk culture consists one of the most suitable fields for modern multicultural education, for the fulfillment of “cultural meeting” and for the appointment of common cultural traits among peoples, without, at the same time, overlooking particularities defined by general and local history (Kakampoura-Tili, 2005b: 267-274).

In Greek educational system a special lesson concerning folk culture was never part of the Curriculum; nevertheless, folk culture was, and still is, present in almost every course taught in primary schools. School handbooks for the courses of Language and Literature (Kakampoura-Tili, 1999: 131145), History -especially local history- ${ }^{16}$, Natural Sciences and Environmental Education, even Mathematics include many aspects of folk culture. Many other school activities and cultural festivities related to gymnastics, theater and art in general also present aspects of folk tradition, as for example traditional dances and representations of traditional customs (Kakampoura-Tili, 2000b: 215-228), shadow theater (Kakampoura-Tili, 2000a: 16-24), tale dramatization (Mponoti, 1999: 49-57). In addition, school festivals connected to the customary holiday cycle (Christmas, New Years' Eve, Carnival, Easter) tend to creatively utilize aspects of folk tradition (Bozikas, 2006: 82-110, 160-269). The benefits, however, of presenting aspects of folklore in classroom have been thoroughly researched and documented (Hanlon, 1999;

Our research aims not to record all folklore-related activities -a difficult undertaking, since many of them are unofficial and collection of related data requires a large research group constantly collaborating with the Ministry of Education-, but those posted on the internet during the period 2000-2013. Nowadays, the Internet, as many researchers agree, has much to offer in the field of communication and cooperation all over the world, but in education as well, as it gives students and teachers alike the opportunity to develop their communicative and research skills and have access to various

\footnotetext{
${ }^{16}$ Local folkloristic studies, utilization of oral sources and fieldwork on a local society, life and family stories comprise areas of modern Greek Folkloristics and are included as suggestions for didactical approach in local history lessons, as can be seen in Leontsinis and Repousi, 2001.
} 
data. Educational activities related to folk/popular -with emphasis to folkculture, when made public on the Internet, present both many examples and options for the implementation of modern or traditional activities inside or outside the classroom, but also function as an inspiration for other educators. They could also function as stimuli for both teachers and students to realize and come to respect, through projects, cultural differences (Burckhalter, 1999. Carico, 2000).

\section{Methodology}

Ethnographical research has adapted to include online data and, generally, the study of cyberspace, as a field of social sciences, either new or supplementary to previous approaches (Hallet \& Barber 2013: 308; Postil \& Pink 2012; Beneito-Montagut 2011; Jones 1998). Our research sample included all Greek kindergarten and primary schools’ webpages, blogs and social media pages. It was conducted between 2011 and 2013, mostly in webpages of the Hellenic School Network ${ }^{17}$. In cases of non-officially activated pages, data was gathered from social media or personal blogs. Several variables were taken under consideration, such as activated or nonactivated pages, website types, educational activity types. Afterwards, educational activities related to folk/popular culture were located and decoded. Finally, combining quantitative with qualitative approaches (Discoll et al. 2007; Savvakis 2012), the data were statistically analyzed in Excel, followed by a qualitative analysis (not presented here).

\section{Descriptive Statistical Analysis}

In the Greek region there are totally 10232 kindergartens and primary schools, public and private: 6040 of them (59,03\%) have activated webpages while 4192 (40,97\%) have not. Public schools seem to dominate in presenting educational activities concerning folk/popular culture on cyberspace.

17 The Greek School Network (www.sch.gr) is the national network of the Ministry of Education, Research and Religious Affairs which safely interconnects all schools of Primary and Secondary education, including educational units abroad. It is the largest, in users, public network in Greece, connecting more than 15.000 schools and a community of 1.350 .000 students and 160.000 educators. It utilizes modern network technology and is among the first five networks on a global level to adopt the IPv6 protocol. See http://www.sch.gr/tieinaitoschmenu/2009-10-04-08-50-34, December 2015. 
Table 1: Rate and percentage of activated and non-activated webpages of Kindergartens and Primary Schools in Greece

\begin{tabular}{|c|c|c|c|c|}
\hline $\begin{array}{c}\text { Kindergartens } \\
\text { and Primary } \\
\text { Schools }\end{array}$ & Activated(N) & Activated(\%) & $\begin{array}{c}\text { Non- } \\
\text { activated(N) }\end{array}$ & $\begin{array}{c}\text { Non- } \\
\text { activated(\%) }\end{array}$ \\
\hline 10232 & 6040 & $59,03 \%$ & 4192 & $40,97 \%$ \\
\hline
\end{tabular}

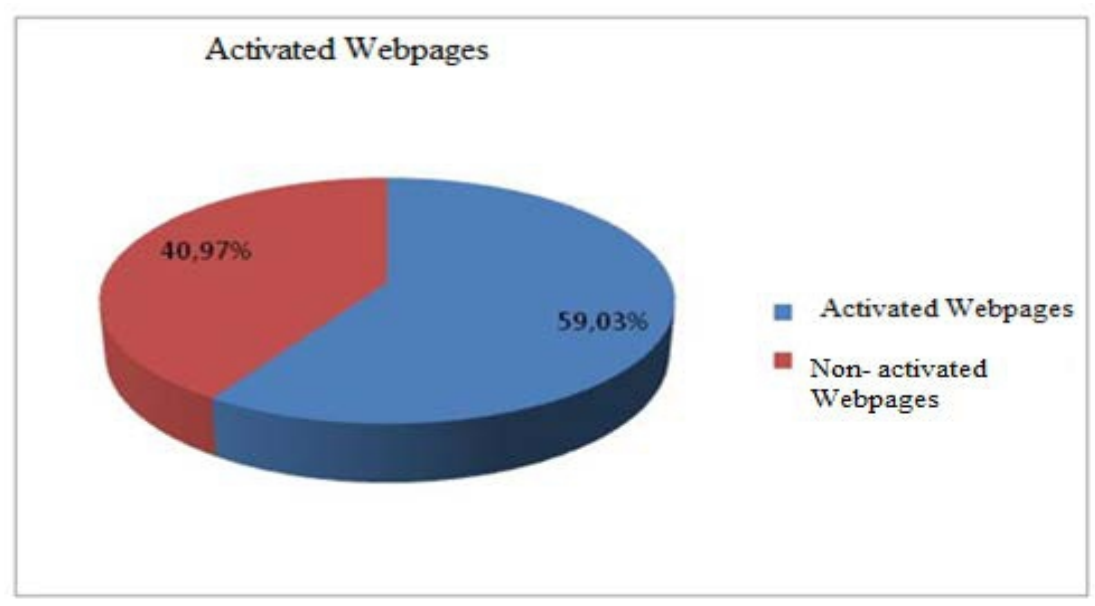

Pie 1: Percentage of activated and non-activated webpages of Kindergartens and Primary Schools in the Greek region.

Table 2: Rate and percentage of active and non- active webpages of Kindergartens and Primary Schools in Greece

\begin{tabular}{|c|c|c|c|c|}
\hline $\begin{array}{c}\text { Kindergartens and } \\
\text { Primary Schools }\end{array}$ & Active (N) & Active (\%) & $\begin{array}{c}\text { Non- active } \\
(\mathrm{N})\end{array}$ & $\begin{array}{c}\text { Non- active } \\
(\%)\end{array}$ \\
\hline 10232 & 1000 & $9,77 \%$ & 9232 & $90,23 \%$ \\
\hline
\end{tabular}

In the Greek region there are totally 10232 kindergartens and primary schools, public and private: 1000 of them $(9,77 \%)$ have active webpages while 9232 (90,23\%) have not. 


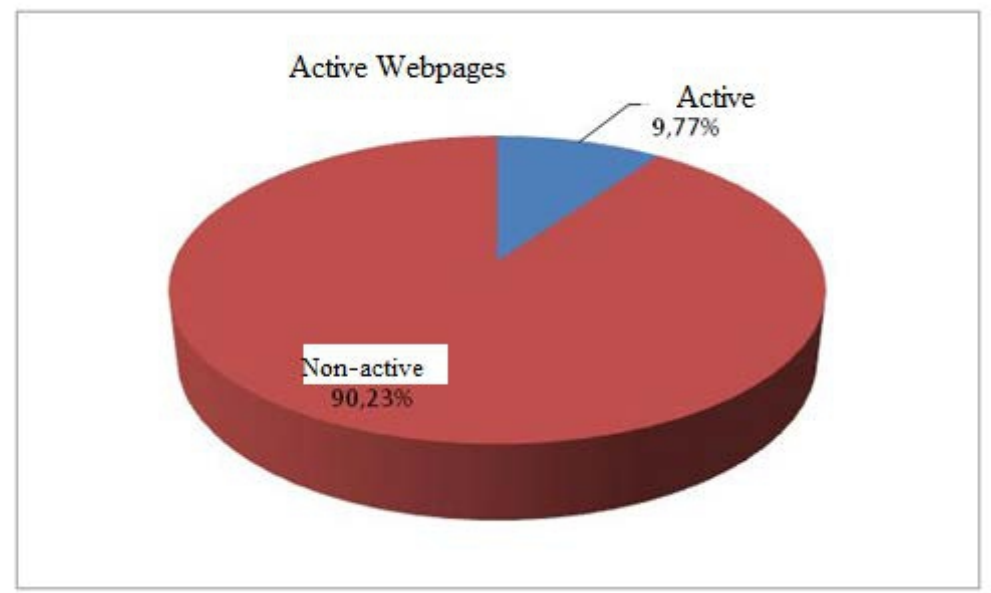

Pie 2: Percentage of active and non- active webpages of Kindergartens and Primary Schools in Greece

According to our research, in webpages mostly and blogs of 606 schools all over Greece, educational activities concerning folk culture were posted. 509 of them (84\%) were from primary schools and 97 (16\%) were from kindergartens.

The types of the above school websites followed next:

Table 3: Websites Types

\begin{tabular}{|c|c|}
\hline Websites Types & N \\
\hline Official school webpages & 390 \\
\hline School blogs & 194 \\
\hline School Facebook pages & 18 \\
\hline Personal teachers' blogs & 2 \\
\hline Personal teachers' webpages & 1 \\
\hline Personal students' blogs & 1 \\
\hline
\end{tabular}

As it can be seen above, 390 official school webpages have been posted, 1 personal teacher's (from these schools) webpage, 194 school blogs, 2 personal teachers' blogs, 18 school Facebook pages and 1 personal student's blog. 


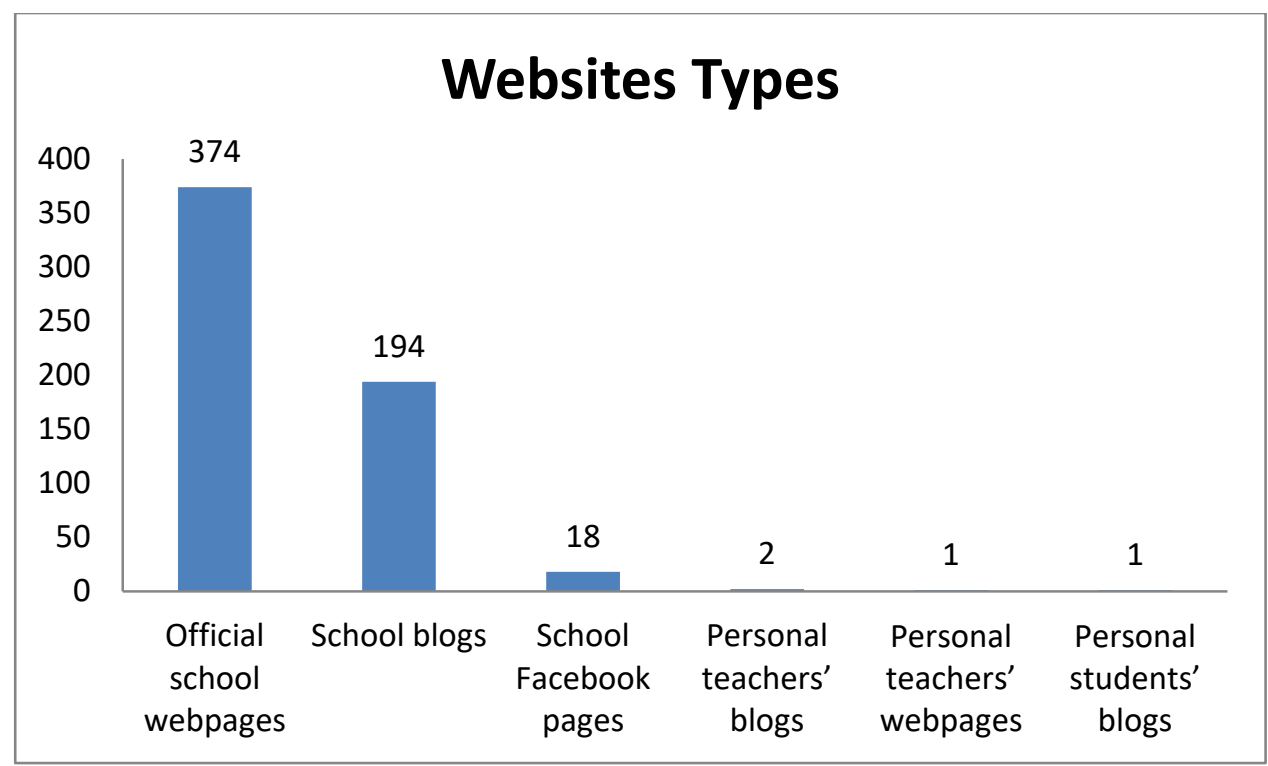

Diagram 1: Websites Types

The next step of our research was to determine the school years that teachers implemented educational activities for folk culture that were posted on websites:

Table 4: School years of educational activities

\begin{tabular}{|c|c|}
\hline School year & $\begin{array}{c}\text { Educational } \\
\text { activities related to } \\
\text { folk culture }\end{array}$ \\
\hline Until 2007 & 142 \\
\hline $2007-2008$ & 44 \\
\hline $2008-2009$ & 72 \\
\hline $2009-2010$ & 117 \\
\hline $2010-2011$ & 206 \\
\hline $2011-2013$ & 1187 \\
\hline No information & 307 \\
\hline
\end{tabular}

As one can see, until $2007^{18} 142$ such activities took place, 44 in 2007-2008 and 72 in 2008-2009. Since 2009-10 there is an increase in posted educational activities (117) and 206 in 2010-2011. In the next two school years, 2011-2013, there is a rapid increase (1187). There were also 307 educational activities for which no temporal data could be found.

${ }^{18}$ In our research, there were a few findings from 1997-8, but the vast majority appears from 2000. 


\section{School Year}

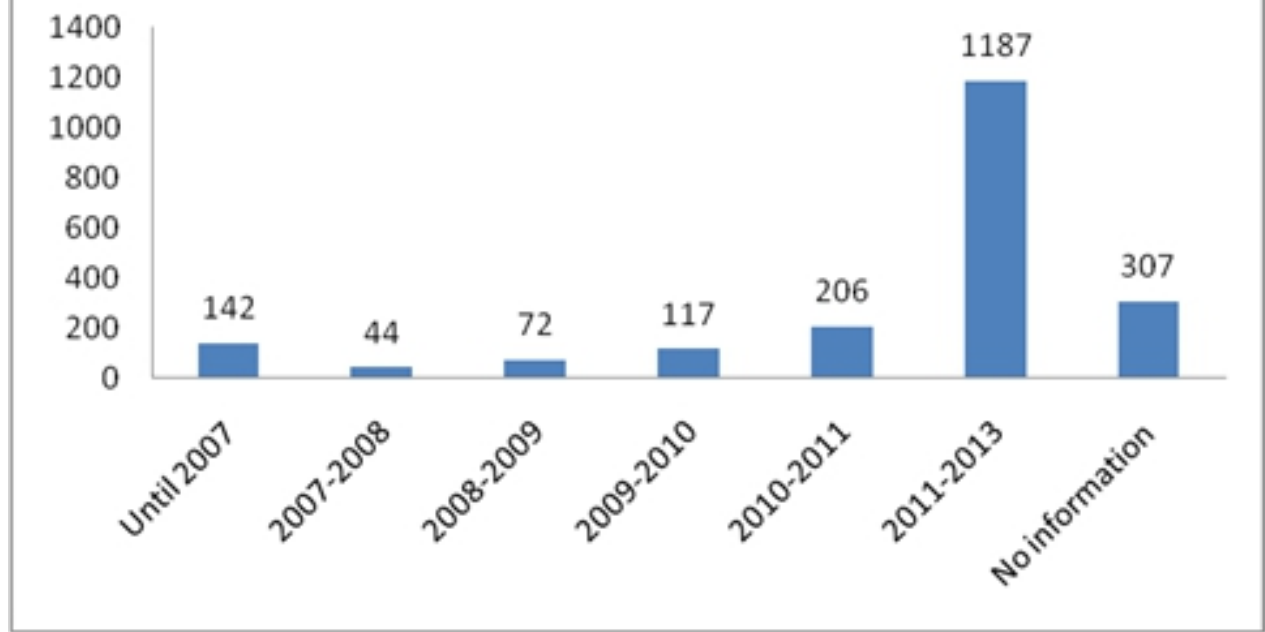

Diagram 2: Postings per school year

The number of postings for every type of activity comes next:

Table 5: Postings per type of folk culture categories

\begin{tabular}{|c|c|}
\hline Folk/Popular Culture Categories & Postings \\
\hline Calendar customs & 856 \\
\hline Material culture & 831 \\
\hline Oral tradition & 376 \\
\hline Traditional dances & 171 \\
\hline Traditional music & 144 \\
\hline Social organization & 107 \\
\hline Shadow theater & 107 \\
\hline Childhood & 91 \\
\hline Rites and rituals of life cycle & 36 \\
\hline
\end{tabular}

As we can see in Table 5, most of the postings (856) refer to customs associated to calendar, mainly Christmas and New Year' eve, Carnival and Easter. A short step behind follow postings concerning material culture (831). There are also many reports about activities related to oral tradition (376). 


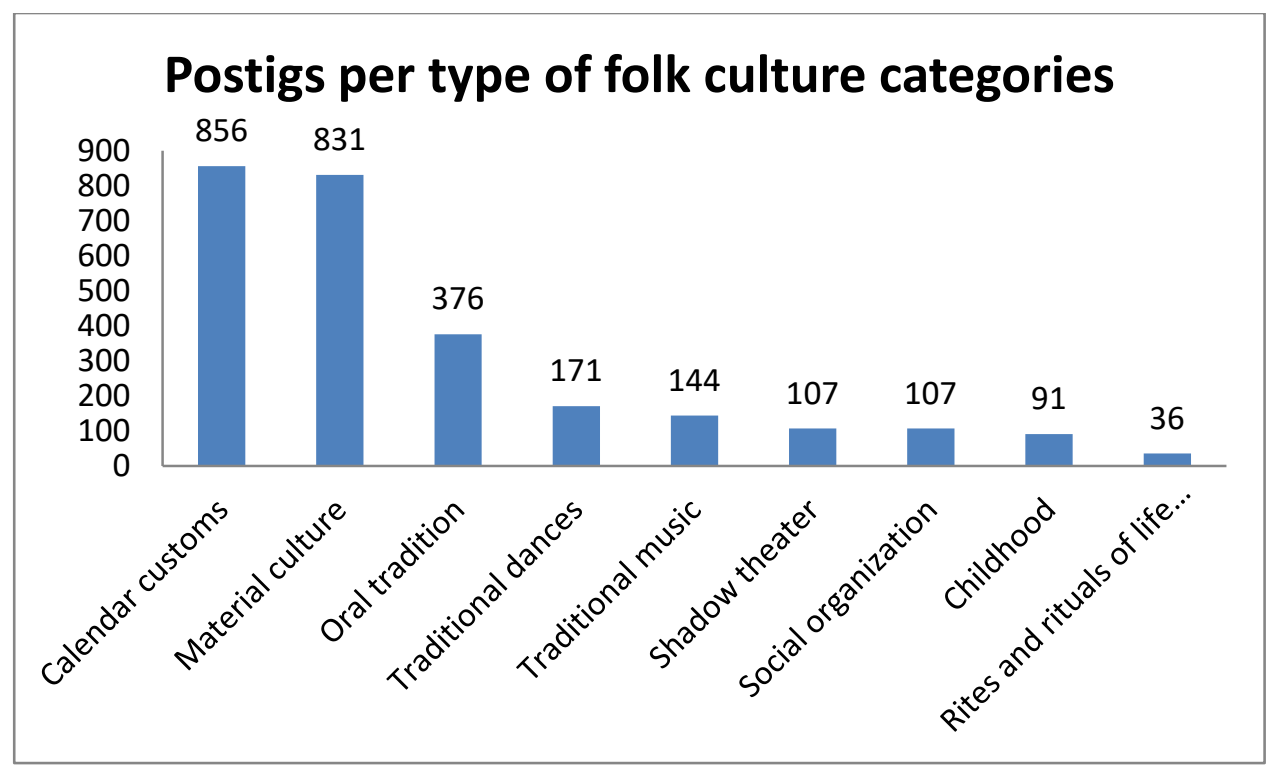

Diagram 3: Postings per type of folk culture categories (according to Meraklis, 2011)

Especially in oral tradition (tales, fables, proverbs, folk songs -as texts-, jokes, legends, wishes/curses) it seems that most postings concern tales. They are presented as theatrical plays and as themes for creative writing projects (adding to or transforming folk tales). Many narrations in schools also take place, while a most favored subject are Aesop's (animal) fables. One folk tale seems to appear more often in educational material: The Twelve Months (ATU 480). There is an extensive use of proverbs, riddles and tongue-ties, usually as articles in school newspapers or in projects related to months' agricultural content. Legends are rarely mentioned, while many carols (Christmas, New Year's Eve) are encountered as texts, incorporated in custom-related activities.

The second category teachers prefer is material culture, viewed in its traditional aspect and its modern transformation and presentation in context of museums and educational programs related to the environment, healthcare and culture. These postings have to do with excursions to folklore museums or creation of collections in school with traditional objects of everyday use from agricultural, pre-industrial life, brought by students (coaloperated clothing irons, spindles and distaffs, wood or metal agricultural tools) or even school objects (old desks, school books, maps, school uniforms, etc.). One can also find much about visits to workshops for traditional products or related to traditional trades extinct today (i.e. baker, hagiographer). There are also museum parks representing traditional arts and demonstrating the gradual revolution with the use of modern technology. Many times artists visit schools and present their trade to students. Nutrition 
is also a common theme for projects, either by preparing traditional recipes in school (usually related to Christmas or Easter customs) or by posting recipes on the internet or as articles in school newspapers. Elderly women (usually students' relatives) often visit schools to prepare in class Greek or ethnic local recipes; these activities are many times incorporated in health care programs. Many activities have to do with traditional clothing, either by students visiting folklore museums or by fabricating clothes' parts (apron, shirt, etc.). There are also activities concerning folk architecture.

Themes that fall under the category of folk material culture are often connected to "social organization-traditional trades" and to "calendar customs”.

In the category of "social organization" one can find extinct or disappearing traditional trades, presented in student projects. These are mostly assignments of seeking related data and text producing by students, interviews from professionals and presentation preparing. Students visit local shops, such as bakeries and cobblers, interview traders about their trade and invite them to school to present it. Sometimes students prepare projects concerning past or present local everyday life.

Most of the activities concerning childhood (91 in total) refer to traditional games, not so as objects but as rules of group games. Many are presented as projects of information gathering or interviewing elderly people about their childhood experience in games; many times children are encouraged to play such games in the schoolyard. There are also many reports about school experience, mainly through pictures posted by teachers in school webpages, without necessarily being part of an activity.

Customs related to Christian Calendar (856) -especially those of Christmas, Carnival and Easter- seem to be the most favored folk culture category for educators. There were many postings about activities at every time of the year, major Greek feasts, the 1st of April or May, but also local versions of the above. Carols are often posted (as texts or sung by children), constructs also, such as kites.

Postings of representations of rituals connected to Rites of passage from the life circle- (Van Gennep, 1960) (birth-marriage-death), while most of these are about traditional wedding. Thus 36 Projects are mostly of local character, such as marriage in Greek regions, like Crete, or Pontus. Postings about christening customs are not very common, with a few exceptions like the custom of seven in Karpathos, which is represented in a local school and could not be left out.

There are 107 activities posted about shadow theater and puppet theater. They mostly relate to Karaghiozes’ plays attended by students. There are many plays with puppets as well. There are also a few related activities of other kinds, like postings about Karaghiozes' creation and two student 
drawings. It is of interest that plays for children share a 'modern' repertoire (i.e. “Karaghiozes the Peace-maker" or "Karaghiozes in 2050”); this fact surely demonstrates shadow theater's evolution and social adaptation. It is a case of folk culture transformed and infiltrating into popular culture. There is also an active participation on behalf of the (children) audience, as they are many times encouraged to watch what goes on behind the curtain or even prepare their own shows.

Celebrations of national holidays in schools are many times accompanied by traditional songs and dances. In activities related to music heritage (144) one can mostly find carols sung by children but also folk songs sung by choirs. There are but a few presentations of folk music tradition by invited speakers. There are 171 postings of Greek traditional dances performances in schools, mostly during national holiday festivities.

Table 6: Activity types in websites

\begin{tabular}{|c|c|}
\hline Activity types & $\mathrm{N}$ \\
\hline Activities & 740 \\
\hline School festivities & 379 \\
\hline Educational excursions & 367 \\
\hline Postings of students' projects & 250 \\
\hline Postings of folkloric data by educators & 160 \\
\hline School newspaper/ Calendar & 145 \\
\hline Cultural programs (Ministry of Education) & 83 \\
\hline Museum or collection creation in schools by students & 71 \\
\hline Environmental programs (Ministry of Education) & 64 \\
\hline Health-care programs (Ministry of Education) & 25 \\
\hline European Programmes: Comenius/ eTwinning & 10 \\
\hline
\end{tabular}

In the case of activity types, all 740 of them have to do with unofficial projects organized by teachers either under the context of the Curriculum, through lessons of language, music, gymnastics, etc., or as part of the 'Flexible' Zone of Cross-Thematic and Creative Activities (EvÉ $\lambda \iota \kappa \tau \eta$

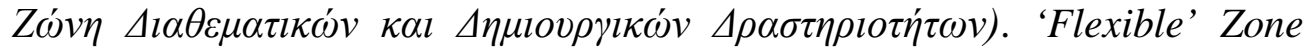
was established in Primary Education in the school year 2000-2001. It constitutes a usually two-hour course in the weekly program. Through free thematic choices and active student-centered methodology, this course aims to counteract the rigid, single-minded and fragmented traditional school program, bringing knowledge through interdisciplinary approaches. There were also few activities under the context of European Programmes, such as Comenius or eTwinning.

Moreover, folk culture themes have been chosen and posted on the internet in 379 school festivities and 367 educational excursions, in 145 school newspapers, 250 students' projects and 160 teachers’ projects. Folk culture related projects have also been recorded in official programs by the 
Ministry of Education, Research and Religious Affairs. Specifically, 83 of them fall under the category of Cultural Programs, 64 of Environmental Education (folk art and traditional techniques) and 25 of Health-Care (Greek agricultural products, Mediterranean nutrition).

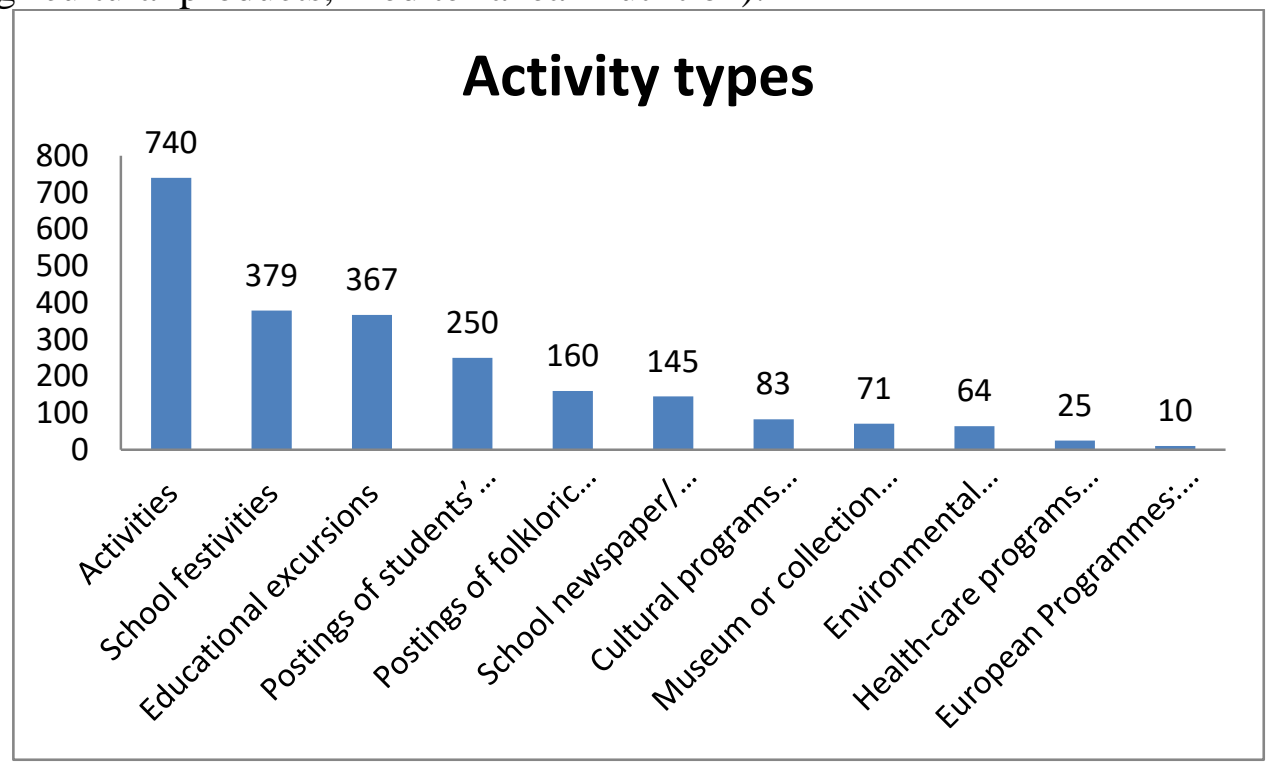

Diagram 4: Activity types in websites

Table 7: Educational Application and Teaching Methods Types in Websites

\begin{tabular}{|c|c|}
\hline Educational application and teaching methods & $\mathrm{N}$ \\
\hline Conjectural - Hand-creations by pupils & 593 \\
\hline Texts by students & 455 \\
\hline Site visits & 380 \\
\hline Choirs & 254 \\
\hline Performances of folk dances & 175 \\
\hline Research of printed or electronic bibliography by students & 151 \\
\hline Presentations by invited speakers & 133 \\
\hline Students watching theatrical plays & 126 \\
\hline Item collections & 103 \\
\hline Students interviewing other persons & 71 \\
\hline Game creation by students & 52 \\
\hline
\end{tabular}

Educational applications have mostly to do with students' handcreations (593), students' theatrical plays (455) and students' texts (380). 


\section{Educational applications and teaching methods}

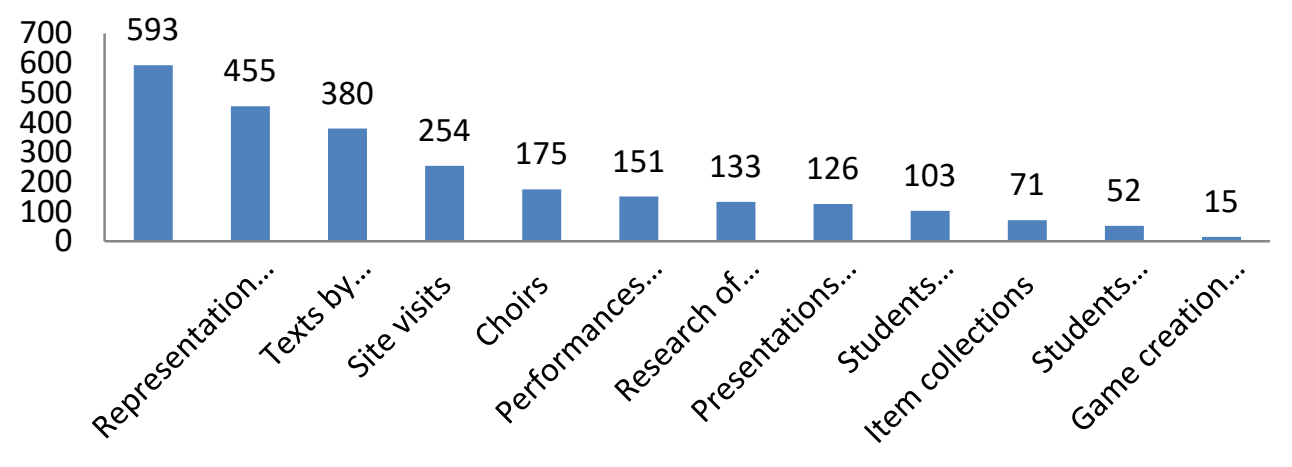

Diagram 5: Didactic applications in websites

In didactic applications folk culture is mostly approached through art (theater, music, dance, painting etc.). For instance, activities connected to traditional customs, the most popular category of folk culture, show a great variation as far as didactics is concerned. There are many artistic representations, custom reenactments, postings of bibliographical projects, postings of teachers' texts, larger school projects, constructions and many Christmas or Easter bazaars where one can buy items created by children.

It seems that (according to material on their websites) most schools demonstrate a wide interest for all-year customs and strive to exhibit and study them and that applies to the last primary grades as well. Kindergartens and the initial primary grades are mostly concerned with constructs or related artistic expression, while later grades produce bibliographical projects.

There are many postings in school newspapers, where one can find various customs, recipes and rituals from all over the world. Customs from other countries are also presented, showing a multicultural dimension in folk culture approach (Kakampoura 2005b: 267-274).

Table 8: Presentation types

\begin{tabular}{|c|c|}
\hline Presentation Types & N \\
\hline Texts & 1626 \\
\hline Photographs & 1492 \\
\hline Music & 404 \\
\hline Videos & 208 \\
\hline
\end{tabular}

As one can notice in the table above, presentations of folk culture through postings include 1626 texts, 208 videos, 1492 photographs and 404 music files. 


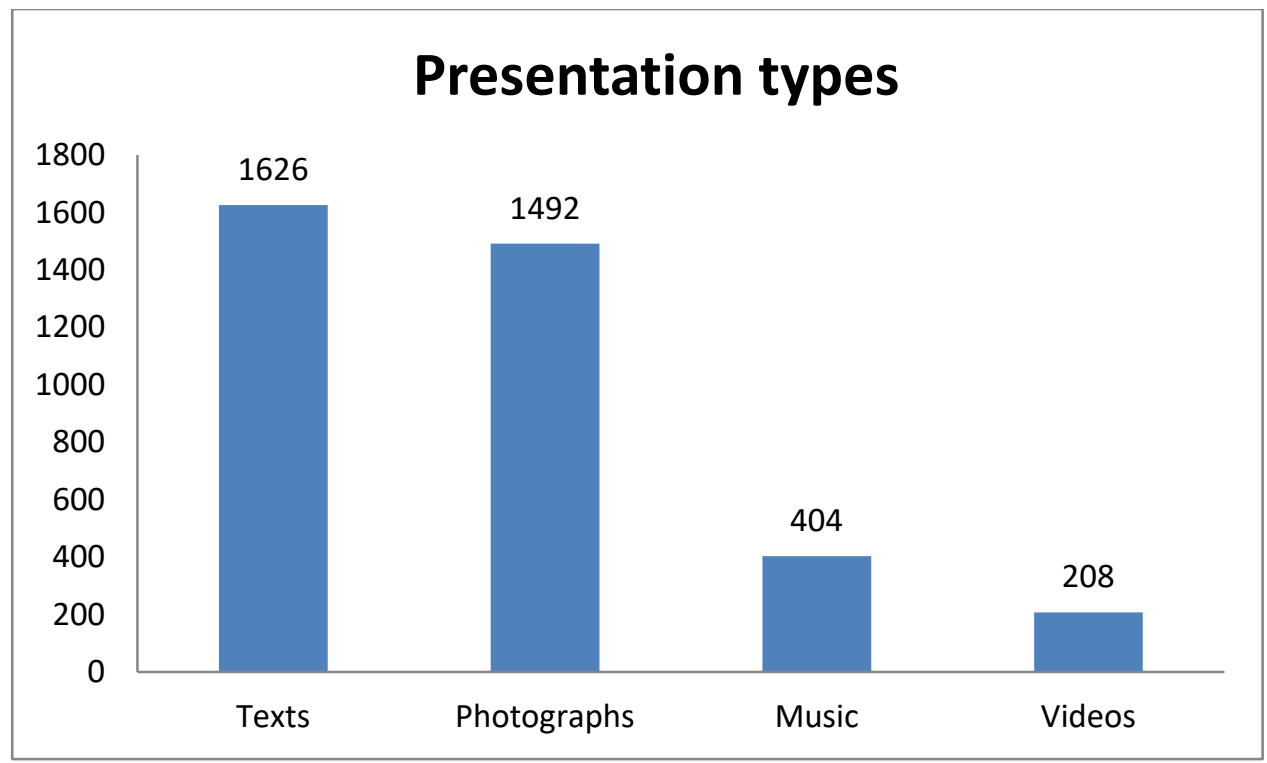

Diagram 6: Presentation types

\section{Final Conclusion}

A great increase in folk/popular culture postings (1187) was noticed between 2011-13. It has to be connected to the New Curricula in the context of New School (School of the 21st century of the Greek Ministry of Education, Research and Religious Affairs). According to these, "Experiential Activities" were established for Primary Schools and Gymnasiums (High School) (104868/Г2/13-09-2011, 124674/Г2/1-11-2011) and "Research Activities" for Lyceums, as distinct units of New School Programs and the new Timetable. The above Experiential and Research Activities, in terms of didactics, are in accordance with Experiential Pedagogy; This approach remains pioneering in matters of education and finds acceptance from educators and modern schools of psychology and sociology. Modern approaches of Experiential Pedagogy, as recorded in recent bibliography ${ }^{19}$ is based on theories and educational applications developed in Europe and the U.S.A. in the first decades of the 20th century, all having in common the activation of students' experience in the educational process. The above surely prove educators' increasing webbased abilities, perhaps also realized though official training programs in computer use.

Folk/popular culture is didactically approached mainly through art (theater, music, dance, painting, etc.), in various projects based on experiential learning, with students actively participating in educational process (Matsaggouras, 2011: 11-12).

${ }^{19}$ See Burton, 2010; Smith and Knapp, 2010; Reynolds and Vince, 2008; Jewell, 2001. 
As for the thematic of folk culture, intangible heritage (rituals, oral tradition, music, dance) seems to outweigh material culture (nutrition, traditional arts and trades). In many projects a dynamic dimension of folk/popular culture is presented, its symbolic aspect of connecting cultural past and present to the students, its transformations and social adaptations. One can also notice an exploitation of folk culture in the context of multicultural education; nevertheless, these outcomes are not of quantitative importance. On the other hand, they demonstrate teachers' trend to present aspects from other cultures, through many noteworthy educational activities, aiming towards cultural awareness as well as respect towards otherness.

\section{References:}

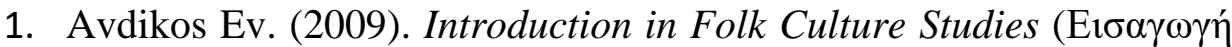

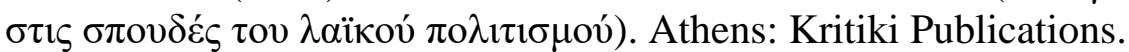

2. Bainbridge, W., S. (2007), «The scientific research potential of virtual worlds», in Science 317 (5837), pp: 472-476.

3. Beneito-Montagut R. (2011). Ethnography goes online: towards a user-centred methodology to research interpersonal communication on the internet. In Qualitative Research, 11 (6) (pp. 716-735).

4. Blank, T., J. (2009a), Folklore and the Internet : vernacular expression in a digital world, Logan, Utah: Utah State University Press

5. Bozikas G. (2006). Customs Cycle and Folk Culture (EӨıนıós

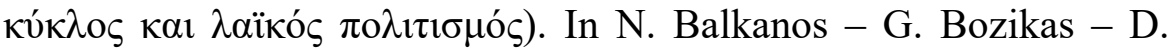
Koutsougeras (Eds) Guide of Cultural Manifestations. $A^{\prime}, B^{\prime}, C^{\prime}$

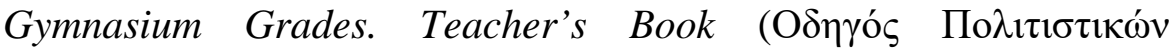

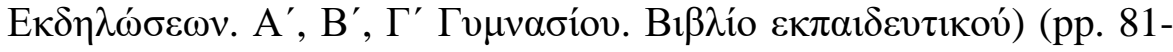
110). Athens: O.E. $\Delta . B$. Publications.

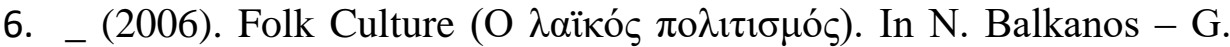
Bozikas - D. Koutsougeras (Eds) Guide of Cultural Manifestations.

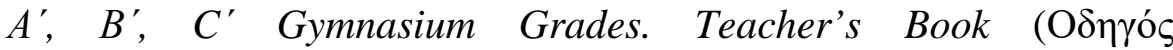

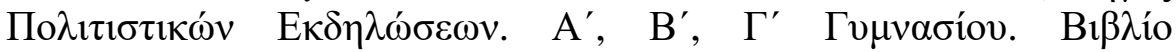
$\varepsilon \kappa \pi \alpha \imath \delta \varepsilon v \tau \iota \kappa o v ́) ~(p p . ~ 160-167)$. Athens: O.E.A.B. Publications.

7. Burckhalter B. (1999). Reading race online. In P. Kollock \& M. Smith (Eds) Communities in cyberspace (pp. 60-75). New York: Routledge.

8. Burton M. (2010). Experiential Education and Social Justice: Philosophical and methodological considerations for integrating experiential learning in educational leadership. ProQuest LLC.

9. Carico K. (2000). On-line multicultural discussions, ERIC document: ED444948. 
10. Van Gennep A. (1960). The Rites of Passage, Manika B. Vizedom and Gabrielle L. Caffee (Transl.). Chicago: University of Chicago Press.

11. Driscoll D., Appiah-Yeboah A., Salib Ph., Rupert D. (2007). Merging Qualitative and Quantitative Data in Mixed Methods Research: How To and Why Not. In Ecological and Enviromental Anthropology, 18, http://digitalcommons.unl.edu/icdwmeea/18 (accessed on 16/2/2017).

12. Hall G. (1987). Minimal selves. In H. Bhabha (Ed) Identity: The Real $M e$, ICA Document 6. London: Institute for Contemporary Arts.

13. Hall St., Held D., McGrew A. (Eds) (1992). Modernity and its Futures, Book IV. U.S.A.: Polity Publications.

14. Hallett Ronald E. and Barber Kristen, Ethnographic Research in a Cyber Era. Journal of Contemporary Ethnography 2014, Vol. 43(3), 306-330.

15. Hanlon T. (1999). General Guidelines for Teaching with Folk Tales, Fairy Tales, Fables, Ballads, and Other Short Works of Folklore. http://ferrum.edu/applit/studyg/studygfolk.htm (accessed on 16/2/2017).

16. Hollins Etta R. (1996). Culture in School Learning. Revealing the Deep Meaning. Lawrence Erlbaum Associates, Inc. Publishers.

17. Jewell D. L (2001). Professional Practicum Manual: Experiential Education in Recreation and Leisure Services: A Workbook for the Recreation and Leisure Studies Practicum: 3rd Edition. Thomas, Charles C. Publisher, Ltd.

18. Jones, Steve (Ed.) (1998). Doing Internet research: Critical issues and methods for examining the Net. Sage Publications.

19. Kakampoura-Tili R. (1999). Linguistic and Literary texts in Primary Education: The Contribution of Folkloristics to their Teaching

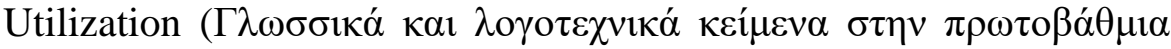

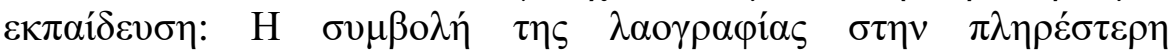

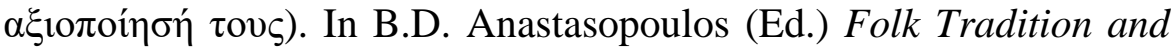

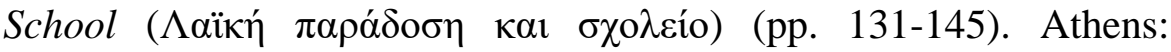
Kastaniotis Publications.

20. _ (2000a). Folk Culture Teaching Program in Primary and Secondary

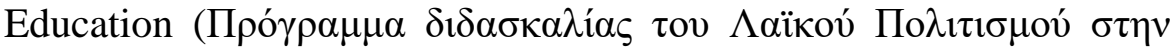

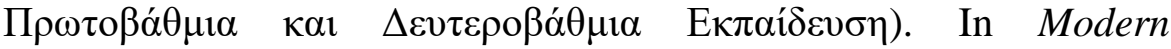
Kindergarten, 14 (pp. 16-24). Athens.

21. _ (2000b). Dramatization of Folk Rituals in the Greek School

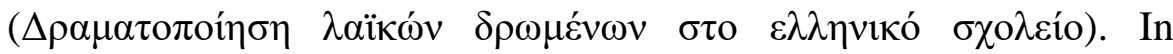
Parnassos, 42 (pp. 215-228). Athens.

22. _ (2005). Folk Culture: A field for Intercultural Education (O $\lambda \alpha$ aïкó $\varsigma$

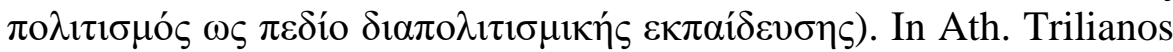


\& I. Karaminas (Eds) Learning and Teaching in the Society of

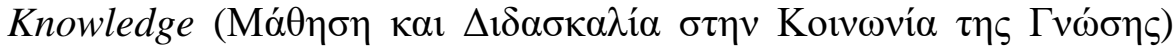
Proceedings of the 5th National Conference, Vol. B' (pp. 267-274). Athens: Faculty of Primary Education U.O.A./ K.E.ЕП.EK.

23. Kaliambou M. (2015). Greek Folktales for Learning Modern Greek. New York: Routledge.

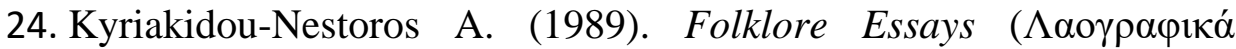
$\mu \varepsilon \lambda \varepsilon \tau \eta \dot{\mu} \mu \alpha \alpha)$, Volume 1. Athens: Company of Greek Literary and Historical Archives.

25. Leontsinis G. \& Repousi M. (2001). Local History as a Study Field

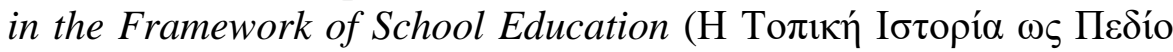

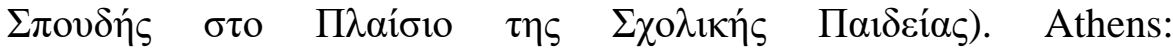

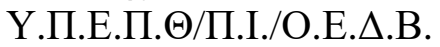

26. Matsaggouras Elias (2011). Educational Material for Experiential Activities: From Experiential Learning to the Cooperative

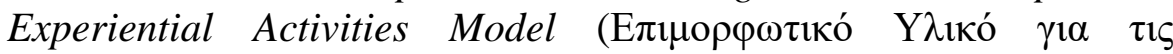

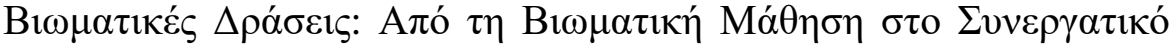

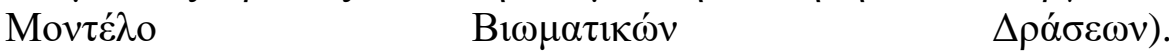

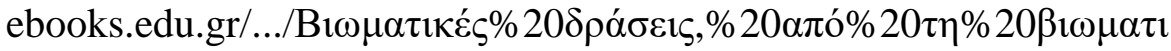
$\kappa \eta ́ \% . .$.

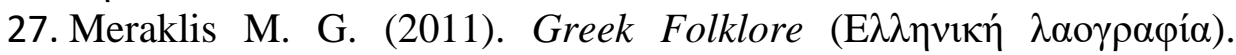
Athens: Kardamitsas.

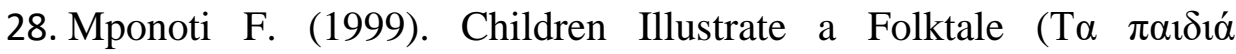

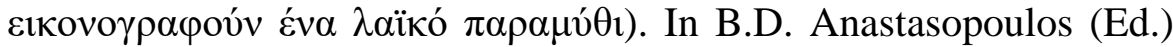

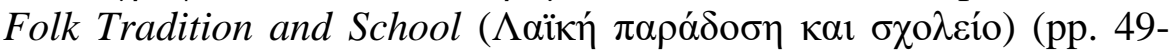
56). Athens: Kastaniotis Publications.

29. Postil J. and Pink S. (2012). Social Media Ethnography: The Digital researcher in a Messy Web. In Media International Australia, 1 (pp. 123-134).

30. Reynolds M. and Vince R. (2008). Experiential Learning and Management Education. New York: Oxford University Press.

31. Savvakis M. (2012). Combining qualitative with quantitative methodologies: a critical overview. In Statistical Review, 8 (1-2) (pp. 53-66).

32. Smith Th. and Knapp C. (2012). Sourcebook of Experiential Education: Key Thinkers and Their Contributions. ProQuest LLC.

33. Storey J. (2012). Cultural Theory and Popular Culture. New York: Routledge. 